\title{
NAS FISSURAS DOS CADERNOS ENCARDIDOS: O BORDADO TESTEMUNHAL DE CAROLINA MARIA DE JESUS
}

\author{
Fabiana Rodrigues Carrijo* \\ João Bôsco Cabral dos Santos ${ }^{* *}$
}

Resumo: Este artigo objetiva referendar a escritura de uma autora que conseguiu alcar voos mais longínquos do que suas limitadas condições socioeconômicas lhe impuseram. Propõe, ainda, mostrar que os escritos de Carolina Maria de Jesus indicam uma cisão conceitual do mundo através de uma ressignificação do discurso do cotidiano e este é materializado através de alegorias severamente vividas. A instância sujeito-autor coloca na experiência empírica de um discurso da exclusão a real experiência da fome e faz deste experimento uma forma de visão social. É inscrito nos aportes teóricos da $A D$ (francesa) que o presente artigo ambiciona olhar para o corpus de base literária, ainda que incanônica, constituída pela obra intitulada Quarto de Despejo - Diário de uma favelada, com vistas a propor um trabalho em interface que, a par de bosquejar os processos de subjetivação, ambiciona, ainda, delinear o que estamos denominando discursividade literária incanônica em Carolina Maria de Jesus.

Palavras-chave: Discursividade literária. Escritura. Carolina Maria de Jesus.

\section{INTRODUÇÃO}

Carolina Maria de Jesus entrevê na escrita a possibilidade de ir além da favela, do quarto de despejo, contudo o faz buscando como modelo de objeto estético literário a norma culta, os tons românticos e ultrarromânticos de autores rastreados no lixo e com os quais buscava meios, artifícios e respaldo para seguir adiante, para ser aceita na cultura letrada. Segundo Sousa (2004, p. 13), “A linguagem fraturada de Carolina deve ser entendida pelo que de fato é: a tentativa de uma pessoa das camadas subalternas de dominar os códigos da cidade letrada." Estamos diante de uma instância-sujeito que criva o mundo, ressignifica-o e o enuncia no entremeio de uma literariedade que busca a inclusão no

\footnotetext{
* Doutoranda em Estudos Linguísticos no Programa de Pós-Graduação em Estudos Linguísticos do Instituto de Letras e Linguística na Universidade Federal de Uberlândia. Membro do Laboratório de Estudos Discursivos Foucaultianos. (LEDIF).Email: facarrijo@gmail.com.

** Professor Associado 2 do Instituto de Letras e Linguística da Universidade Federal de Uberlândia. Doutor em Estudos Linguísticos pela UFMG. Coordenador do Grupo de Pesquisa Laboratório de Estudos Polifônicos. Email: sjohnny@terra.com.br.
} 
universo discursivo da literatura como forma de inserção social. Trata-se, pois, de uma tentativa de deslocamento de um lugar social de pobreza e miséria para um lugar discursivo imaginário de constituição pelo seu dizer sobre si. Um exercício de alteridade da e pela linguagem que lhe confere uma autoria como forma de emergência de um sujeito do mundo nele próprio.

Em outras palavras, no artigo intitulado Experiência e representação: 0 feminino, o latino-americano, Richard (2002, p. 149) profere:

Vários textos do feminismo latino-americano operam com este ideologema do corpo (realidade concreta, vivência prática, conhecimento espontâneo, biografia cotidianas, oralidade popular), que encarna a fantasia de uma América Latina animada pela energia salvadora do compromisso social e da luta comunitária, cujo valor documental e testemunbante seria julgado politicamente superior a qualquer elaboração teórico-discursiva. Esta relocalização da mulher (vivência, ação, "experiência pessoal"), da imediatez do fazer (vivência, ação, experiência, compromisso) com seus emblemas domésticos e cotidianopopulares, faz par com uma imagem do feminino/latinoamericano, que o simboliza como o "outro" selvagem (preconceitual) da academia.

Não é sem razão que Carolina opte pela escrita e entreveja nela uma possível ascensão e/ou porta entreaberta para os seus textos. No entanto, após um período de existência, seguiu-se um silenciamento total para autora e obra, ambos fadados ao esquecimento. Tanto Carolina quanto o livro Casa de Alvenaria, publicado com os recursos advindos do sucesso editorial de Quarto de Despejo, não receberam os acenos da crítica literária e do mercado editorial da época. Em consequência desse esquecimento, a referida autora preferiu se recolher em um sítio em Parelheiros. Fora lá que passou seus últimos anos até vir a óbito em 1977. O caráter autobiográfico-ficcional-realista de seus textos enuncia de si num ethos outro, o da literatura, o da inserção e aceitação social, o da condição humana digna. A própria escrita nessa discursividade se revela enquanto alteridade de uma forma-sujeito da miséria que se 
transpõe para um lugar discursivo de ser humano inserido em um mundo possível.

É instigante, quase um contrassenso pensar que alguém, para ter acesso ao mundo letrado - entenda-se, aqui, literário -, tenha de fazê-lo lançando mão de um tipo de forma, de padrão literário que já o exclui, de antemão. Sair do subterrâneo, do processo de submissão e tentar infiltrar-se em um processo outro, em um viés outro para mostrar justamente o quarto de despejo, o subsolo, a periferia da cidade. Vê-se a emergência de um sujeito em interpelação que procura na escrita, na literatura, nos modelos literários, uma forma de deslocamento de sua condição ideológica.

\section{REFERENCIAL TEÓRICO: ALGUMAS NOTAÇÕES TEMÁTICAS E METODOLÓGICAS}

Carolina, o sujeito-autor, se diferencia de outros favelados por ter-se permitido ir para além do quarto de despejo (o espaço físico favela). Ela se singulariza por ser uma catadora de sonhos (ainda que pegos/catados na leitura de autores românticos, ainda que obtidos por uma memória discursiva que anuncia e enuncia a leitura de Casimiro de Abreu, Castro Alves, dentre outros entrevistos em Quarto de Despejo diário de uma favelada (1960). Estes mesmos sonhos e inspiração encontrados no lixo, nos papéis revoltos das ruas por Carolina Maria de Jesus. Assim, os sonhos de Carolina - tanto o sujeito empírico (aquele sujeito do mundo) quanto o sujeito discursivo (enquanto instância e/ou função assumida pelo autor em uma dada discursividade) - perpassavam pela rudeza das sucatas, mas entremostravam as auspiciosas aspirações de uma mulher favelada, pobre, semiescolarizada, provedora única de três filhos e um barraco e, ainda, confabuladora de uma 'escrita de si' que evidencia as rasuras de um sujeito em ininterrupto embate com as palavras.

\footnotetext{
${ }^{1}$ Doravante, apenas QD, seguido do número da página, já que todos os excertos são e serão retirados da $1^{\mathrm{a}}$ edição de Quarto de Despejo, 1960. Cumpre mencionar que essa obra não passou por uma revisão gramatical; nesse sentido, os referidos excertos entremostram as singularidades de um sujeito-autor que, enquanto sujeito empírico, pertencente a uma dada comunidade, só cursou até o segundo ano primário, em uma Escola Espírita de Sacramento denominada Allan Kardec.
} 
O sujeito-autor, para recorrermos aqui a uma das funções e/ou posições possíveis propostas por Foucault (2009), tenta traduzir a matéria local: a favela e os seus problemas diários, apostando na possibilidade de harmonizar as misérias reais que evidenciam a fonte/origem de seu dizer para estabelecer um dizer outro. Um dizer que, justamente por tratar do real, pode parecer/configurar estranho para outros que não o vivenciaram e/ou não o vivenciam. Daí a necessidade premente de se fazer ouvir, de se fazer lida, para mostrar, ainda que em uma linguagem pretensamente dicotômica, híbrida, (re)vela/(des)vela as mazelas humanas fazendo com que o real, o periférico se tornem universal, digno de nota e, talvez por esta razão, digno de ser lido.

É um exercício de autoria que significa a história pelo crivo de um protótipo de estética, dito consagrado, com o intuito de buscar legitimidade de enunciação, a expressão literária de um realismo cotidiano, traduzido em sentidos da constituição de uma instância-sujeito que esboça uma tomada de posição perante seu lugar social. Assim, uma estetização desse real por um viés romântico/ultrarromântico instaura uma espécie de legitimação de um cotidiano que necessita de representação.

Seguindo, ainda, as considerações de Richard (2002, p. 149, grifos do autor):

Ainda que seja certo que as batalhas descolonizadoras, as lutas populares e as convulsões ditatoriais na América Latina gestaram texto e conhecimento fora do cânone livresco (nas margens informais e subversivas do extra-acadêmico), emblematizar esse corpo de experiências como a única verdade do feminismo latinoamericano (sua verdade primária e radical; radical por extrateórica) vem a confirmar o estereótipo primitivista de uma outra "outricidade" que só tem vida através de afetos e sentimentos. Esta "outricidade" é romanceada pela intelectualidade metropolitana, que concebe o popular e o subalterno, o feminino e o latino-americano, como uma espécie anterior à tradução, de modo que deixa intacta a hierarquia representacional do centro: um centro que continua hegemonizando, assim, as mediações teórico-conceituais do 
“pensar", enquanto relega a periferia à empiria do dado, para sua sociologização ou antropologização através das histórias de vida e do testemunho.

A instância enunciativa sujeitudinal - para recorrermos aqui às extensões principiadas por Santos (2009) - Carolina Maria de Jesus lança mão de um recurso narrativo inovador para a época (final da década de 1950, princípio de 1960), a narrativa em diários e/ou relatos memorialísticos, especialmente oriundos das penas, das mãos de uma mulher, e antecipa, em dez anos, este tipo de gênero textual materializado por escritores (homens), e se vale dele para alinhavar/tecer um relato, em que os fios discursivos, embora chamuscados de dor, entremostram a memória de uma mulher negra, semiescolarizada, favelada, mãe solteira, moradora da favela do Canindé e catadora de lixo.

Ao se tomar Carolina Maria de Jesus como instância enunciativa sujeitudinal, observa-se o jogo de alteridades entre a forma-sujeito pobre, o lugar social 'excluída' e o lugar discursivo sujeito de si pela inserção literária. A materialidade linguística por essa instância produzida inaugura a singularização de uma modalidade de expressão estética que se consagraria na temporalidade de uma causalidade estética da modernidade. O caráter memorialista instaura, também, a alteridade autor/personagem como uma relação sujeitudinal dialética, pensada na perspectiva de expressar uma evanescência do cotidiano como elemento de perpetuação de uma historicidade do sujeito.

Fios e agulhas em mãos carolinianas tecem/destecem/alinhavam/suturam e cerzirão um discurso literário incanônico, para utilizarmos aqui um neologismo que possa indicar, em uma de suas acepções, o fato de a crítica literária especializada da época não enquadrá-lo dentro dos cânones da referida ocasião. Trata-se de uma incanonicidade que desvela o caráter de unicidade da própria tentativa de apropriação de características de uma literatura romântica e/ou ultrarromântica. Nesse sentido, a crítica não poderia reconhecer o produto estético de uma individuação em nível de autoria, uma vez que assim quebraria os dogmas de uma erudição ad referendum.

Assim, conforme Sousa (2004, p. 158), 
a tessitura narrativa de Carolina, que compreende também a linguagem que lhe serve de meio para representar a realidade na qual vive, se é truncada e rasurada, é porque dá a ver as contradições que operam dentro da sociedade. $O$ fato de Carolina, como diz Marisa Lajolo (1996), estar na contramão do momento literário dos anos 60, quando a literatura buscava na cidade, na cultura de massa, meios para criar uma linguagem literária que respondesse àquele momento histórico, na verdade, evidencia a exclusão social - que é também cultural, e se assim é, é também de gosto, uma vez que o padrão de gosto de Carolina não corresponde ao da época. E se não corresponde é porque está fora dos circuitos da elite dominante.

Em uma leitura ingênua, ficamos indignados, quando não amofinados, ao constatar o que afirmava Virgínia Woolf (em outras condições materiais, intelectuais, enfim, sob outras condições de produção histórico-ideológica e cultural): de que a mulher que escrevia, que quisesse lançar mão de ser escritora,deveria fazê-lo quando, de fato, tivesse um teto todo seu; no caso de Carolina Maria de Jesus, ela não tinha e não chegou a ter estabilidade financeira, pelo contrário, fora sempre destituída de qualquer estabilidade possível. ${ }^{2}$

Carolina, em meio ao caos, literalmente, em meio ao lixo, encontra nos cadernos encardidos recolhidos deste mesmo lixo a possibilidade entreaberta de sair de seu limitado mundo e confabular meios - entendase, aqui, materiais, intelectuais e financeiros - para prover os seus e provê-los com o dinheiro advindo da escrita. Sua escritura que, a despeito de ter e ser um valor testemunhal inegável, (re)vela uma autenticidade do vivido, (des)vela, ainda, uma espontaneidade de sua consciência de mulher, mãe, favelada, escritora, consciente, delatora e/ou relatora das ocorrências da favela e/ou - para nos servirmos de uma

\footnotetext{
${ }^{2}$ Um teto todo seu é uma das obras consagradas de Virginia Woolf. Fizemos uma analogia entre a autora (Virgínia) e a obra, já que em outros países, como, especialmente, no Brasil, é imprescindível ao escritor ter certa estabilidade financeira antes mesmo de se iniciar no ofício de escritor, já que sobreviver da escrita é quase impossível, sobretudo porque não há, entre outras coisas, uma política de valorização da leitura e do escritor. Por isso insistimos, no texto acima, que ter um teto todo seu é condição sine qua non para se começar a escrever, já que o produto da escrita (os livros) é dispendioso - demanda recursos financeiros e tempo de um(a) autor(a). Nessa obra, sobretudo nas condições de produção que a engendraram, já se falava da necessidade de se possuir estabilidade financeira antes de se empreender o ofício da escritura.
} 
metáfora elaborada pelo sujeito-autor (Carolina Maria de Jesus) -, denunciante do Quarto de Despejo.

Se há valor testemunhal, há e haverá ainda uma representação, uma abstração, um simulacro desse mesmo real, desta feita, transfigurado em discurso literário, ainda que incanônico, pois quem estabelece o que seja ou não canônico também o faz lançando mão do que é e/ou está sendo produzido na referida época, a supor que outros textos com outras características e/ou oriundos das mãos de uma mulher negra, favelada, mãe solteira, pobre, descendente de escravos, dentre outras atribuições, fatalmente não estariam dentro do intitulado 'cânone'.

Essa testemunhalidade advém, principalmente, da alteridade constituinte dessa representação. Uma alteridade que imbrica papéis sociais, projeta estereótipos sociais e ratifica vislumbres sujeitudinais nunca antes idealizados nos meandros literários. Tal representação de uma 'escrita de si' singularizada entremostra os deslocamentos do sujeito permeados pela interpelação da linguagem frente aos olhares sobre os mundos possíveis.

Não é sem razão que, se tivermos contato com os textos/os manuscritos originais de Carolina, facilmente identificaremos uma escritura que precisa, ininterruptamente, grafar com força, com toda a força possível (necessidade de escrever e reescrever, fortemente, sua história) se materializando em um texto como se ele fosse sempre um palimpsesto, uma escritura em palimpsesto. A escrita em palimpsesto é utilizada aqui com a concepção que era dada pelos gregos, não só no sentido literal, mas na acepção de raspar o texto e reescrever, fortemente, por cima, deixando à mostra aquela versão primeira. Sem contar que Carolina já escrevia em cadernos que eram retirados do lixo e, neste caso, já evidenciavam, já traziam em si uma página amarela, folhas arrancadas, descoladas e (re)aproveitadas - um dizer já alterado/retalhado e outro que seria, intensamente, reescrito nas folhas/nas fissuras dos cadernos encardidos.

Essa escrita 'por sobre' revela uma historicidade que pertence a uma anterioridade que determina o lugar social do sujeito, trazendo a superposição de outra escrita que, por uma alteridade em clivagem, revela o lugar discursivo da instância enunciativa sujeitudinal escritora. Dessa forma, a alteridade 'por sobre'/'superposição' significa essa 
movência sujeitudinal que constitui uma forma-sujeito que se traduz por seu lugar social e faz emergir uma tomada de posição revelando o lugar discursivo autor. Ao mesmo tempo, não se pode deixar de registrar o deslocamento simultâneo entre os três lugares (posição-sujeito, lugar social e lugar discursivo), síntese da criação literária que se enuncia nos cadernos encardidos.

Carolina Maria de Jesus - enquanto instância-sujeito que congrega inúmeras posições possíveis, a saber: sujeito-autor; sujeito-narrador; sujeitopersonagem -, ao criar um relato em que a personagem é protagonista de uma história/estória, desvela uma escritura em que as marcas do sujeitonarrador, do sujeito-personagem e, ainda, do sujeito-autor resvalam em um tipo de relato autobiográfico, como já sugere o título Quarto de despejo: diário de uma favelada (1960), mais precisamente, em um diário íntimo que, a par de revelar o preço dos alimentos, dos transportes, também faz uso do chamado "discurso citado" para testemunhar, dar cunho de veracidade aos relatos.

Segundo Sousa (2004) não basta para Carolina citá-los, é preciso lançar mão desse recurso para testemunhar (com uma autenticidade possível) os comentários de outros favelados, de outros moradores, de outras personagens. É imperioso comprovar que eles, de fato, existiram, ainda que tenha que recorrer - não raras vezes - ao tom de ameaça aos seus vizinhos e personagens do seu diário, prometendo citar nome, endereço, profissão e até mesmo número do documento de identidade.

O estranho diário de Carolina é utilizado para recorrer, aqui, ainda que de maneira avizinhada, ao título de uma tese ${ }^{3}$ cunhada com o desejo de explicitar sua escritura. Tal explicitação faria emergir na obra da escritora a marca legítima de um cânone - os românticos e ultrarromânticos. Ao tentar reproduzir este cânone, Carolina Maria de Jesus o singularizou e reportou-se a outro gênero textual, mais tipicamente próximo dos textos memorialísticos. QD acaba por apresentar uma discursividade outra, fora do cânone literário vigente, que denominamos, aqui, incanonicidade.

\footnotetext{
${ }^{3}$ Tese de doutoramento de Germana Henriques Pereira de Sousa, intitulada Carolina Maria de Jesus O Estranbo Diário da Escritora Vira-lata, defendida em 2004 na Universidade de Brasília, ilustra os desdobramentos de sua escritura.
} 
A existência de um diário se constitui como um elemento revelador das condições de produção da obra da escritora. Condições de produção que trazem à tona temáticas, sentidos recorrentes, índices de interpelação da instância-sujeito em sua clivagem com o mundo e a sociedade em que vivia. Essas temáticas, sentidos e enfoques de interpelação fazem emergir elementos da memória, da história e da anterioridade discursiva de uma época, de um grupo social e de um legado de acontecimentos e condições de vida que significam a evanescência sentidural da obra da escritora.

Como proceder diante de um texto que, a todo momento, se nos apresenta enquanto uma figura de linguagem chamada oxímoro? Como se portar diante da materialidade discursiva em que as funções-autor, narrador, personagem, dentre tantas outras possíveis, se apresentam dispersas, quando não imiscuídas e não raras vezes inseparáveis? Como apreender um sujeito-autor que em um processo de interpelação - nos moldes que apregoara Pêcheux (1997, p. 148) - promovem a constituição de um sujeito que é chamado à existência?

Carolina é, prontamente, ininterruptamente, instigada/incitada à existência: seja para apresentar aos outros a favela e a miséria dos favelados (seus iguais); seja, ainda, para se destacar deles, por possuir, por ambicionar deter a cultura letrada para, a par dela, e utilizando-a enquanto ferramenta, alçar voos longínquos ou tão somente revelar ao mundo sua condição de negra, favelada, mãe solteira, catadora de lixo e escritora.

Se o sujeito se constitui na e pela ideologia e traz tatuado/inscrito em seu processo de subjetivação (no ato de se constituir, ininterruptamente, sujeito) um lugar social, uma posição social, uma formação discursiva e, consequentemente, um lugar discursivo, Carolina Maria de Jesus, o sujeito-autor, a partir de uma dada condição ideológica, política, social, histórica, no espaço limítrofe do barraco no 05 , na Rua A, da Favela do Canindé quer crer que a escrita, a escritura é uma profissão possível, pretendida, ambicionada. Mesmo cônscia de suas limitações correlacionadas à cultura intitulada letrada, padrão, infiltra-se no mundo literário ou, conforme expressa Lajolo, "arromba" a literatura, provocando fissuras no arcabouço desta "república das letras brancas e cultas", "mundo das concordâncias e das crases" (LAJOLO, 1996, p. 43 44 , grifos da autora). 
Há na materialidade discursiva apreendida no corpus literário incanônico de Quarto de Despejo inscrições dicotômicas, reveladoras de marcas de oralidade e marcas de um discurso mais próximo dos textos românticos ou 'letrados'. Essas inscrições se sobrepõem na alteridade da produção de sentidos e da constituição da instância-sujeito na emergência da obra. Dicotômicas porque se deslocam, transmutam-se, movem-se signicamente no encaminhamento da enunciação literária.

Segundo a fortuna crítica de Carolina Maria de Jesus, notadamente os textos oriundos de áreas antropológicas e sociológicas, especialmente os escritos por José Carlos Sebe Bom Meihy e Robert M. Levine, a autora só detinha o segundo ano primário. Toda a leitura que o sujeitoautor Carolina entremostra em QD, apreendida por meio dos sentidos veiculados nessa obra e, também, entrevistos nas diversas marcas no interdiscurso caroliniano, fora tateada/buscada/burilada nos moldes tomados enquanto cânone - os poetas românticos, entre eles Casimiro de Abreu, primeiro poeta a ser lido e tomado como referência, dentre outros, como Castro Alves, aceito e referendado pela autora como um dos grandes poetas, o poeta dos pobres, das minorias, dos excluídos.

É estimulante o fato de que a instância-sujeito Carolina Maria de Jesus, apesar da baixa escolaridade, tenha adquirido tanto em termos de letramento - nos moldes do que pontuara Magda Soares (1999): como práticas sociais efetivas de leitura e escrita. Segundo Marisa Lajolo, ao prefaciar a Antologia pessoal de Carolina Maria de Jesus com o título Poesia no Quarto de Despejo, ou um ramo de rosas para Carolina, Carolina tem uma escrita que, a despeito de apresentar a cultura popular, a fala do povo, os erros de sintaxe, os inúmeros erros de concordância, as rimas pobres, as canções populares, a trova/prosa oriunda, advinda de seus ancestrais negros - o avô descrito como um Sócrates africano - mostra, entremostra, delineia o exercício, o pesado exercício de buscar/garimpar, recolher os termos/vocábulos mais próximos do dicionário, mais elitistas, mais incomuns, mais atípicos de uma cultura fartamente anunciada como subletrada. Uma tessitura singular que desvela o exercício do dizer, um exercício inacabável do dizer...

Carolina escreve e se inscreve como um sujeito-autor, um sujeitonarrador um sujeito-personagem marcado/circunscrito/cerzido/alinhavado - para recorrermos aqui aos vocábulos correlacionados à tessitura, ao exercício de alinhavar, cerzir, 
costurar o dizer - e ao cosê-lo tenta remendar, alinhavar um lugar possível para o discurso caroliniano.

$\mathrm{O}$ que seria esse discurso caroliniano? Uma conjuntura de sentidos em efeito que revela a referencialidade polifônica de uma instância-sujeito que enuncia pela significância de uma discursividade tomada como literária. Efeitos de uma historicidade, de uma anterioridade discursiva, de uma memória discursiva que insere a instância-sujeito escritora em um ethos socioeconômico-literário, para enunciar um pathos resultante de sua clivagem e interpelação de um mundo possível que vivencia e sobre o qual e a partir do qual produz um logos que se inscreve em uma amplitude linguístico-estético-literária.

É paradoxal que Carolina Maria de Jesus tome como molde os poetas românticos, o verso com rima, os motes do amor, da saudade, do amor à pátria quando na ocasião - década de 1960 - eram outros os conceitos, os moldes: havia a necessidade de justamente pôr fim ao verso, à forma, à convenção, como apontavam os modernistas:

Contemplava extasiada o céu cor de anil. E eu fiquei compreendendo que eu adoro o meu Brasil. O meu olhar posou nos arvoredos que existe no inicio da rua Pedro Vicente. As folhas movia-se. Pensei: elas estão aplaudindo este meu gesto de amor a minha Patria. [...] Toquei o carrinho e fui buscar mais papeis. A Vera ia sorrindo. (QD, p. 36)

Esqueceram de informar a Carolina, como bem pontuara Lajolo, quais eram os modelos denominados canônicos, literários:

E, como não tinha sido informada, Carolina ia ao dicionário apesar dos tropeços e do peso do cartapácio. E o resultado são os poemas salpicados de lantejoulas do quilate de abscondado, desídias, estentóreo, recluída, cafua, infausto, cilícios, ósculos, agro, olvida-me, érebo, e similares ourivesarias falsas, que dão a seu livro um indesejado tom de pastiche involuntário (LAJOLO, 1996, p. 52-53). 
Não obstante o prefácio referendar um livro de poemas, postumamente editado, o comentário acima também se assemelha à materialidade discursiva entrevista na obra que constitui o corpus de análise deste artigo, qual seja, QD. A escritura de Carolina é paradoxal, ela abriga, congrega, quando não metamorfoseia o dizer, recorrendo às chamadas "lantejoulas" ${ }^{4}$ para abrilhantar, para enfeitar, para adornar o discurso pobre, miserável, destoante do dito progresso econômico, político, cultural anunciado. As lantejoulas também são indicativas do desejo do sujeito-autor de pertencer, de tatear outro lugar discursivo, outro lugar social, um lugar legitimado, talvez acadêmico/canonizado para o seu dizer tão miserável e que mesmo sendo, se intitulando, se apresentando humilde tem sonhos vastos, tem sonhos auspiciosos.

Se os sonhos são verdes, se os sonhos são ditosos, a realidade é negra, é dura, é sofrível, é roxa - "cor da amargura que envolve o coração dos favelados" (QD, p. 34) é repetível, pois os dias são sempre iguais, os relatos são/serão sempre os mesmos: a busca pela sobrevivência, a luta, a embravecida luta pela sobrevivência quando, em muitos momentos, o sujeito-narrador, ao relatar as agruras dos favelados, os aproxima dos corvos quando não os apresenta como inferiores a estes e outros animais:

As aves deve ser mais feliz que nós. Talvez entre elas reina amizade e igualdade. [...] O mundo das aves deve ser melhor do que dos favelados, que deitam e não dormem porque deitam-se sem comer. (QD, p. 35)

Deus é o rei dos sabios. Êle pois os homens e os animais no mundo. Mas os animais quem lhe alimenta é a Natureza porque se os animais fossem alimentados igual aos homens, havia de sofrer muito. Eu penso isto, porque quando eu não tenho nada para comer, invejo os animais. (QD, p. 61)

Só há beleza, só haverá beleza e ela se acha concretizada na metáfora da banha frigindo na panela, ou ainda, quando há feijão com arroz e a promessa de uma refeição, ainda que parca, ainda que carente dos nutrientes necessários.

\footnotetext{
${ }^{4}$ Recursos linguageiros de uma expressividade linguística que ilustra e caracteriza representações de um dizer que reflete um realismo acontecimental, isto é, da ordem do acontecimento.
} 
Pelos enunciados já citados, o que se observa é a diversidade de inscrições, de formações discursivas distintas. De acordo com os estudos pecheutianos, a formação discursiva é o lugar da constituição do sentido (PÊCHEUX, 1997, p. 162) É nesta acepção que empregamos a aludida notação temática.

Chamaremos, então, formação discursiva aquilo que, numa formação ideológica dada, isto é, a partir de uma posição dada numa conjuntura dada, determinada pelo estado da luta de classes, determina o que pode e deve ser dito (articulado sob a forma de uma arenga, de um sermão, de um panfleto, de uma exposição, de um programa, etc.). Isso equivale a afirmar que as palavras, expressões, proposições, etc., recebem seu sentido da formação discursiva na qual são produzidas: retomando os termos que introduzimos acima e aplicando-os ao ponto específico da materialidade do discurso e do sentido, diremos que os indivíduos são "interpelados" em sujeitos-falantes (em sujeitos de seu discurso) pelas formações discursivas que representam "na linguagem" as formações ideológicas que lhes são correspondentes. (PÊCHEUX, 1997, p. 160-161, grifos do autor)

Ora, Carolina se revela a escritora dos pobres e de suas agruras; ora ela se apresenta como a delatora dos favelados e de suas lambanças, fugindo e/ou fingindo escapar às suas misérias; ora ela se exibe como a apaziguadora, aquela pessoa que, por acreditar e se reconhecer escritora, é a única expectativa dos seus companheiros de miséria. É sempre ela que põe fim às brigas, às discórdias, é sempre ela que abranda os mexericos... é sempre ela que é porta-voz dos favelados. É ela, também, que em muitos momentos controversos, para não dizer paradoxais, parece intuitivamente desvelar uma inscrição que a apresenta como uma mulher à frente do seu tempo. Escolhe criar os filhos sozinha, opta por não ter marido e não se sujeitar a apanhar e, ainda, ter que sustentar a casa como fazem muitas de suas vizinhas, que trabalham fora e ainda parecem tambor, apanham de seus companheiros.

Em outros enunciados há referência ao preconceito contra os imigrantes nordestinos, proferindo que são sempre eles a se meter em confusão, são sempre eles a iniciar uma briga, são sempre eles os 
preguiçosos, cachaceiros, baderneiros; tal atitude resvala em uma atitude pré-concebida, quando não preconceituosa.

Há inúmeras inscrições do sujeito-autor em uma dada discursividade política, ideológica, social, literária, dentre tantas outras possíveis. Carolina, enquanto sujeito-autor, em inúmeros momentos fala/descreve a necessidade de $\mathrm{o}$ poeta estar vinculado àquilo que registra. Ela se reconhece como uma poeta dos pobres. Insiste-se aqui no termo 'poeta' e não 'poetisa', a supor que aquele não carrega em si nenhuma acepção de gênero (masculino e/ou feminino) e porque a própria Carolina também usa o termo/vocábulo poeta. A escrita não tem gênero, aliás, não tem sexo: "Vi os pobres sair chorando. E as lagrimas dos pobres comove os poetas. Não comove os poetas de salão. Mas os poetas do lixo, os idealistas das favelas, um expectador que assiste e observa as trajedias que os políticos representam em relação ao povo". (QD, p. 54)

Meihy (1996, p. 17), ao referendar, junto com Lajolo, a obra intitulada Antologia pessoal de Carolina Maria de Jesus, publicada postumamente, pontua que:

Carolina escrevia muito. Não só músicas - sambinhas pobres também foram perpetrados por ela - mas, ao lado de múltiplos gêneros, principalmente, versos agarrados nas linhas do simplismo, da rima mais que fácil e da repetição. Carolina foi e era por definição poeta. Sequer dizia-se poetisa. Sem entender o significado disto, tudo que for dito sobre ela soará pouco e, mais que incompleto, vazio. (MEIHY, 1996, p. 17)

Carolina escreveu diários, teatro, letras de música, poesia, romance - ela perpassou por diversos gêneros textuais, embora tenha ficado conhecida apenas como a autora de diários íntimos. Essa diversidade de escritura literária funda-se na necessidade de uma expressividade sujeitudinal inscrita em uma discursividade literária que a revelasse como instância-sujeito nesse universo discursivo. Trata-se de uma constituição sujeitudinal plural em busca de um lugar discursivo que a revelasse enquanto instância enunciativa sujeitudinal escritora. 
Na materialidade discursiva de QD se faz possível identificar, assinalar diversos recursos utilizados para compor o dizer. Trechos carregados de metáforas, textos (des)veladores dos motes utilizados nos textos de Casimiro de Abreu, em Castro Alves, o uso de metáforas, o recurso da hipercorreção - quando a instância-sujeito Carolina, sabendose não possuidora do código letrado, tenta se infiltrar nesse código e se corrigir - de tal modo que chega ao exagero ou, ainda, abeira-se ao que se conhece como hipercorreção: uso exagerado dos pronomes, escolha de vocábulos burilados, garimpados nos dicionários. Nesse sentido, o dizer de Carolina traz tatuada a marca do interdiscurso. E é inegável, em muitos momentos, para recorrermos aqui às expressões apontadas por Umberto Eco (1994), que o sujeito-leitor (re)conhece trechos, falas, verbetes, transcrições de outros discursos, de outros autores, notadamente os autores românticos. Veja-se este fragmento:

Contemplava extasiada o céu cor de anil. E eu fiquei compreendendo que eu adoro o meu Brasil. O meu olhar posou nos arvorêdos que existe no inicio da rua Pedro Vicente. As folhas movia-se. Pensei: elas estão aplaudindo este meu gesto de amor a minha Patria. [...] Toquei o carrinho e fui buscar mais papeis. A Vera ia sorrindo. E eu pensei no Casemiro de Abreu, que disse: "Ri criança. A vida é bela". Só se a vida era boa naquele tempo. Porque agora a epoca está apropriada para dizer: Chora criança. A vida é amarga. (QD, p. 36)

Nessa perspectiva, é possível cotejar a posição de Maingueneau (2006, p. 72) quando discute a noção de discurso constituinte:

Como todo discurso constituinte, a literatura mantém uma dupla relação com o interdiscurso: de um lado, as obras se alimentam de outros textos mediante diferentes procedimentos (citações, imitações, investimento de um gênero...) e, do outro, elas se impõem à interpretação, ao emprego.

É assim que o sujeito-autor ou a instância enunciativa sujeitudinal escritora faz uso do que lera, do que ouvira, daquilo com que tivera CARRIJO; SANTOS - Nas fissuras dos cadernos encardidos... 
contato, e (re)toma esses outros dizeres com outras acepções. Não é, de maneira alguma, mera reprodução, mas um outro dizer, marcado por outras inscrições sociais, políticas, históricas, ideológicas e culturais. Senão seria apenas uma réplica dessas inscrições sem uma clivagem do mundo que significativamente enunciasse e referendasse o que disse Maurice Blanchot (1996, p. 8), quando argumentou que o que importa não é dizer, mas redizer e, neste redito, dizer a cada vez uma vez primeira.

Pelos excertos supracitados é facilmente perceptível uma releitura e/ou uma relocalização dos enunciados, dos vocábulos, das expressões fundadoras do estilo romântico de alguns escritores, entre eles, Casimiro de Abreu, Castro Alves e o próprio Gonçalves Dias com o poema Canção do exílio, que exalta a terra, os bosques, as várzeas, as flores, os amores.

Conforme assevera Pêcheux (1997, p. 162, grifo do autor),

o próprio de toda formação discursiva é dissimular, na transparência do sentido que nela se forma, a objetividade material contraditória do interdiscurso, que determina essa formação discursiva como tal, objetividade material essa que reside no fato de que "algo fala"" (ca parle) sempre "antes, em outro lugar e independentemente", isto é, sob a dominação do complexo das formações ideológicas.

\section{CONSIDERAÇÕES FINAIS}

A instância enunciativa sujeitudinal escritora Carolina Maria de Jesus é/representa um grito de protesto contra as injustiças cometidas contra os favelados, as minorias, os pobres. Sua voz é contundente, cáustica. Neta de escravos, seu discurso entremostra em 'pé de garrafa' a exemplo do mito africano ${ }^{5}$ - as migalhas, a dor, a complacência com os

\footnotetext{
${ }^{5} \mathrm{O}$ Pé de Garrafa é um ente que vive nas matas e capoeiras. Dificilmente é visto. Contudo ouvem sempre seus gritos agudos ora amedrontadores ou tão familiares que os caçadores procuram-no, certos de tratar-se de um companheiro ou parente perdido no mato. E quanto mais o procuram, menos o grito lhes serve de guia, pois, multiplicado em todas as direções, desorienta, atordoa, enlouquece. Então os caçadores acabam perdidos ou voltam para casa depois de muito esforço para reencontrar o caminho conhecido. Quando isso acontece sabem tratar-se do Pé de Garrafa. Logo poderão encontrar os vestígios inconfundíveis de sua passagem, claramente assinalado por um rastro
} 
desvalidos e, ainda que, não sendo homem para mudar o curso da história, sonha com o mundo das letras, com o mundo dos adeptos do dom da palavra - aqueles que são mais abastados culturalmente e socialmente providos de tradição letrada.

Talvez, nesse sentido, o discurso caroliniano revele uma leve aproximação com o mundo de Alice - na medida em que confabula sonhos e ambiciona torná-los possíveis. Este será seu dedal de mudança, possível legado aos seus irmãos de cor. O dizer de Carolina é simples, contundente, direto, sem meios-tons, sem o requinte da sofisticação, embora se encontrem espalhadas algumas lantejoulas aqui e ali, para recorremos ao comentário feito por Lajolo (1996). O que esta autora chama de lantejoulas são algumas metáforas, algumas expressões atípicas para alguém com tão pouca escolaridade formal. Sua singularidade se revela não somente na denúncia social, mas, ainda, na possibilidade de criar artifícios ficcionais para desvelar a singularidade de sua denúncia. Deitar e acordar com lápis e papel na mão não é uma atitude puramente mecânica, é uma singularidade que desvela, na ação de escrever e de catar, a probabilidade de catar sonhos/realizar sonhos feitos os de Alice no país das maravilhas, de Carroll - a despeito de crer, de ter a lucidez de ver e entrever que os lugares já estão postos, que as injustiças se repetem, ininterruptamente, tais como os elementos frasais com que iniciam seus dias esquadrinhados em seu diário.

Carolina sonha com um mundo utópico, ideal, em que homens e bichos sejam tratados com dignidade; aliás, em muitos momentos de desespero, chega a crer que os animais são privilegiados, pois conseguem se alimentar, enquanto os favelados, em inúmeros momentos, não têm o que comer. Carolina representa a figura de uma catadora de palavras para calar/sufocar a fome do não saber institucionalizado; por outro

redondo, profundo, lembrando perfeitamente um fundo de garrafa. No mito do Saci Pererê há a menção a uma ave, de nome Mati-Taperê ou Peitica, que deu origem ao mito da Matinta Pereira, cujo canto, semelhante a um grito de lamento, ecoa em todas as direções, deixando confuso quem o escuta, assim como acontece com o enigmático grito do Pé de Garrafa. Na obra de Carolina, especialmente QD, entremostra-se uma possível alusão aos gritos do pé de garrafa - não no sentido literal, mas no sentido outro, qual seja, o de deixar salpicados no texto vestígios de uma escritura singular do sujeito-autor Carolina. Assim, insiste-se em que se faz possível rastrear nesse discurso caroliniano marcas de uma discursividade singular a evidenciar os gritos, os protestos de dor, de lamento e de injustiças cometidas contra aqueles que moram no Quarto de Despejo (a favela) e espiam e aspiram à sala de estar, no caso, morar na cidade de São Paulo com toda a infraestrutura necessária.

CARRIJO; SANTOS - Nas fissuras dos cadernos encardidos... 
lado, não dissonante deste, também configura a catadora de sonhos para criar/confabular/engendrar um universo de sobrevivência possível.

As páginas de cadernos amarelados pela ação do tempo chegaram às mãos de Audálio Dantas como que por coincidência. Por uma obra do acaso, ou, como diria Guimarães Rosa (2001), pela força do acaso que conspira, ainda que o "viver seja um descuido prosseguido". Estava o jornalista andando na favela - à procura de artifícios para engendrar um relato sobre os favelados, quando, como por uma eventualidade, ouve falar de Carolina - a favelada que anotava tudo o que ocorria na favela. Sacada de gênio ou mera obra do acaso? O fato é que encontrou ali alguém que, sendo da favela, poderia falar muito melhor em nome desta; isto daria mais veracidade ao testemunho.

O tempo de Carolina é o tempo do Era uma vez, ainda que estabeleça uma possibilidade de porvir, de tornar a ser, ainda que antecipe em 10 (dez) anos a escrita em diário, feito/concebido por uma mulher. Era uma vez uma menina que desde sempre havia sido destinada a ser poeta... Por isso, recorrendo a sua memória, ao senso comum e ao relato de um médico, quando frequentemente sentia dores na cabeça... ele retrucava/sentenciava que ela havia nascido para ser poeta... Era este o seu destino, era esta a sua sina. Carolina ambicionava ser poeta; mais do que isto, desejava sobreviver desta escritura, e outra vez... relembramos Alice no país das maravilhas: "Enquanto escrevo vou pensando que resido num castelo cor de ouro que reluz na luz do sol. Que as janelas são de prata e as luzes de brilhante. Que a minha vista estou no jardim e eu contemplo as flores de todas as qualidades." (QD, p. 39)

Assim, em 1958 aparece Audálio Dantas metamorfoseado em Chapeleiro Maluco - bem, no caso de Carolina, não tão maluco assim, já que ele, em sua antevisão jornalística, apura e prepara um contexto editorial favorável para receber Carolina Maria de Jesus - um achado. Alguém que, vindo da favela, seria seu porta-voz. Nada mais convincente em um país que se abria, ainda que, ilusoriamente, para a popularização, para a democratização da cultura, mostrar a favela por seu próprio ângulo, pelo seu próprio viés. 
$\mathrm{Na}$ aludida ocasião houve talvez uma confluência de astros: o acaso, a escrita, a mensagem, os leitores, só faltou - e talvez este seja o aspecto que tenha recebido maior aceno de Carolina - o ressentimento, o ressentir-se pela falta de receptividade da crítica literária à sua obra, e pela mesma razão também entremostrou a não aceitação de Carolina aos cânones literários vigentes.

Talvez date daí sua frustração, sua fuga para o sítio de parelheiros e para seu processo de encapsulamento. Se por parte dos leitores teve uma audiência/uma aceitação imensa - superando em um só dia até mesmo autores considerados clássicos, como Jorge Amado -, por outro lado, e dissonante deste, não fora aceita pelos poetas de salão, pelos ditos acadêmicos e/ou imortais, mesmo tendo sido Quarto de despejo um dos livros mais lidos no Brasil, quiçá no mundo, na década de 1960.

Carolina sentou-se e olhou as páginas em branco que pretendia preencher com o saldo de sua solidão e de suas carências pessoais, emocionais, financeiras. De forma atabalhoada, começa a entender que a vida é determinada pelas escolhas e estas já foram a priori determinadas pelas diferenças culturais, sociais, políticas, profissionais, étnicas e, ainda, de gênero - o peso, o árduo peso de ser mulher: negra, favelada, mãe solteira e com baixa escolaridade. E ela, a instância-sujeito Carolina Maria de Jesus, como tantos, sempre tivera dificuldade em escolher. Talvez, justamente, porque as escolhas já estavam postas a priori. Nesse momento, a sua era uma vida tão encapsulada que parecia ser impossível chegar ao cerne, à origem deste enovelamento. A sua história é multifacetada. Realizando uma remota comparação entre a obra Alice no país das maravilhas e a obra Quarto de despejo, de Carolina Maria de Jesus pode-se dizer que esta é repleta de fantasias oníricas e lúdicas acerca da realidade e da linguagem.

São simbolizações e alegorias que, a um primeiro parecer, contestam a lógica e o senso comum primando pelo non-sense, pelo absurdo. Contudo, como a própria instância-narradora profere: "há de existir alguém que lendo o que escrevo dirá isto é mentira, mas as misérias são reais"; o non-sense é só aparente, só quem passa pela fome é que sabe o que é sentir a fome, segundo esta mesma instância-sujeito narrador profere: "a fome tambem é professora" (QD, p. 31). 
Essa ludicidade desvela, contudo, metáforas lúcidas a respeito do mundo e da sociedade, da divisão entre favelados/miseráveis e ricos; entre o quarto de despejo e a sala de estar. A instância-sujeito Carolina Maria de Jesus transpõe para a materialidade linguística e discursiva o mundo lúdico de Alice, embora o faça ao revés... Seu mundo é a favela, são as marginais da cidade de São Paulo - cheias de incertezas e ilogicidades. São Paulo, como no país das maravilhas, é dividido/cindido em castas/classes... proletários e classe média. Carolina, a catadora, representa/configura a carta de espada (os servidores, os jardineiros, os pedreiros, os proletários, os desvalidos, os jogados para o quarto de despejo).

QD e a sua recepção entremostram os matizes da favelada, um quadro em que as cores primárias e secundárias não são associadas ao belo, antes ao cheiro de podridão, aos entretons cinzentos e esfumaçantes da poeira, da lama, do mau cheiro, da pinga, da imundície que exala da favela, trazendo à mostra a metáfora dos desvalidos esfomeados - quando, então, passado o boom editorial, autora e obra são silenciadas.

Contudo, o livro QD cresce no mercado editorial nacional e internacional, alça voos desmedidos, trazendo esta metáfora dos desvalidos e esfomeados; a academia, porém, faz vista grossa ao mercado editorial crescente para o Quarto de despejo.

"Era uma vez"... a vida da instância-sujeito Carolina Maria de Jesus é repleta de questionamentos existenciais: a fome, a luta contra o tempo para catar, enovelar, dormir, sonhar, tornar possível, trabalhar... A incoerente realidade externa não se coaduna com a realidade interna. Não é suficiente ser diferente do modelo social de um determinado momento histórico. É preciso diferenciá-lo, trazer à tona o que era apenas vago e sufocador - para recorrermos aqui aos dizeres de Clarice Lispector. ${ }^{6}$

\footnotetext{
${ }^{6}$ Clarice Lispector - renomada escritora brasileira -, quando inquirida sobre o que era escrever, respondia prontamente para uma de suas entrevistadoras, a jornalista Laura Aguiar: "Escrever é procurar entender, é procurar reproduzir o irreproduzível, é sentir até o último fim, o que permanecia apenas vago e sufocador."
} 
Era imperioso modificar esse momento histórico, ainda que em folhas catadas no lixo. Tal atitude desvela coragem, muita coragem. QD, metaforicamente, revela um rito de passagem para a coragem: a coragem de ser mulher, a coragem de ser mãe, a bravura de resistir à fome e utilizá-la como pauta para a denúncia social, política e histórica, a força de SER só no mundo, o ônus de ser uma mulher negra, semiescolarizada, favelada, mãe solteira, catadora de lixo e escritora. Carolina Maria de Jesus devolve ao seu país, por intermédio de seu discurso, dedais de projetos que visam às minorias sociais. Talvez essa seja a melhor, a única porção que lhe cabia, talvez essa seja a atitude de uma 'Cinderela negra da modernidade' com sua pequena varinha de condão - principiar as denúncias, revelar as mazelas que afligem os favelados, os seus iguais.

Carolina propõe uma cisão conceitual do mundo por meio de uma ressignificação do discurso, e esse discurso é materializado através de alegorias vividas - duramente, severamente vividas. A instância-sujeito autor coloca na experiência empírica do discurso a real experiência da fome e faz desta experiência uma forma de visão social.

A propósito, observando as considerações foucaultianas bem delineadas no livro O que é um autor? (2009), bem como as páginas iniciais dos prefaciadores do livro, mais vale o projeto de empreender uma tentativa de rascunhar uma 'escrita de si', portanto acreditar-se no gesto de superar, que nas próprias superações; "a própria escrita (grafia) é um gesto da vida, e que, se a pode negar, destruir, banalizar, também a pode "salvar"' (2009, p. 8-9). Talvez pelo exercício de catar o lixo e salvaguardar os dias vividos haja, no corpo de QD, um projeto social, literário e filosófico do sujeito autor Carolina Maria de Jesus de protegerse da própria solidão, salvar-se da loucura, defender-se da miséria que consome os sonhos e os engaveta nos escaninhos obscuros da memória.

Carolina Maria de Jesus - enquanto posição-sujeito desestabilizou o posto, se permitiu ir além do quarto de despejo, ousou um atrevimento: possuir uma casa de alvenaria ${ }^{7}$, considerado na época

\footnotetext{
7 'Casa de alvenaria' está sendo usado aqui em duplo sentido: o primeiro deles, talvez mais premente, é a casa de alvenaria conquistada por Carolina com a vendagem do seu primeiro livro, a saber: Quarto de despejo - diário de uma favelada (1960) e, na segunda acepção, também se refere a outro livro, bancado, desta feita, pela própria autora, com o dinheiro ganho na edição de Quarto de despejo. Livro que não recebeu os acenos do público nem da mídia, e igualmente do meio acadêmico, como uma
} 
um atrevimento de negrinha metida, "arrombou" a literatura da ocasião, no dizer de Lajolo (1996), provocou fissuras no meio jornalístico, e ainda que não tenha sido considerada uma autora da ordem do cânone, desestabilizou o posto e acreditamos que tenha fundado/estabelecido uma discursividade outra para além do cânone. Inventariou um legado que lhe permitiu escrever diversos gêneros discursivos: teatro, poemas, canções, cartas, novelas, diários (o conhecido), dentre outros.

Carolina sai do anonimato, desestabiliza, quebra regras, ainda que tenha o intuito de seguir a norma considerada padrão, a norma culta; incomoda por não ser possível imputar-lhe uma categoria, uma etiqueta. Carolina fere todas as etiquetas legitimadas e rotuladas como aceitáveis para ser considerada uma escritora: ser escolarizada, ter formação clássica e vir de uma camada social mais abastada. Carolina - enquanto sujeito empírico - é negra, favelada, pobre, mãe solteira, semiescolarizada, descendente de escravos e leitora autodidata. Assim, reciclava lixo e ao reciclá-lo entrevia uma realidade outra, acreditava no poder da escrita como forma de anotar os dias e preservá-los do esquecimento. Tentava, ainda, registrar as lambanças de seus irmãos de cor e apontar os deslizes deste e daquele governante. Tinha uma coragem para além do prontamente esperado; ao reciclar lixo, mantinha o desejo de um dia mudar o curso da história, separava lixo e trocava por gêneros alimentícios em uma época em que nem se falava em reciclagem. Resgatou e preservou seu instinto primeiro de escriturar e inventariar o que é e seria da ordem do não inventariável: a vida infame dos homens comuns. E se sua 'escrita de si' abespinha-se é também porque desestabiliza o posto, esfola regras, funda um novo campo discursivo e ousa falar da vida cotidiana com todas as suas singularidades, com toda a precariedade e inalterabilidade dos dias, em que vida privada e pública se entrelaçam no quarto de despejo (espaço privado, o quarto de Carolina), mas contracenam aos olhos de todos os favelados, no meio da favela (no quarto de despejo, espaço público), no centro paupérrimo do descaso e dos desvalidos, lá onde jorram todas as estórias e escórias da cidade, quiçá do país.

grande expectativa cultivada por Carolina. Assim, tanto a autora como os livros publicados após seu best-seller Quarto de despejo foram fadados ao esquecimento. 


\section{REFERÊNCIAS}

AGUIAR, L. Entrevista de Clarice Lispector à jornalista Lara Aguiar. Disponível em: < http:/ /www.wagnerlemos.com.br/clarice.htm>. Acesso em: 11 ago. 2012.

BLANCHOT, M. Conversação infinita. In: COMPAGNON, A. O trabalho da citação. Tradução de Cleonice P. B. Mourão. Belo Horizonte: Editora UFMG,1996.

CARROLL, L. Alice no país das maravilhas. Porto Alegre: L\&PM, 2009.

ECO, U. Seis passeios pelos bosques da ficção. Tradução de Hildegard Feist. São Paulo: Companhia das Letras, 1994.

HAK, T.; GADET, F. (Orgs.). Por uma análise automática do discurso: uma introdução à obra de Michel Pêcheux. Tradução de Bethania S.Mariani et al. 3. ed. Campinas, SP: Editora da Unicamp, 1997.

FOUCAULT, M. O que é um autor? Tradução de Antônio Fernando Cascais e Eduardo Cordeiro. 7. ed. Lisboa: Passagens, 2009.

JESUS, C. M. de. Quarto de despejo - diário de uma favelada. V. 1. São Paulo: Linográfica Editora Ltda., 1960. 182 p. (Coleção Contrastes e Confrontos) . Casa de alvenaria. São Paulo: Francisco Alves, 1961. Antologia pessoal. Org. José Carlos Sebe Bom Meihy. Rio de Janeiro: Editora UFRJ, 1996.

GUIMARÃES ROSA. Grande sertão: Veredas.19ª ed. Rio de Janeiro: Nova Fronteira, 2001.

LAJOLO, M. Poesia no quarto de despejo, ou um ramo de rosas para Carolina. In: JESUS, C. M. de. Antologia pessoal. Org. de José Carlos Sebe Bom Meihy; [revisão de] Armando Freitas Filho. Rio de Janeiro: Editora UFRJ, 1996.

MAINGUENEAU, D. Discurso literário. São Paulo: Contexto, 2006.

MEIHY, J. C. S. B. O inventário de uma certa poetisa. In: JESUS, C. M. de. Antologia pessoal. Org. de José Carlos Sebe Bom Meihy; [revisão de] Armando Freitas Filho. Rio de Janeiro: Editora UFRJ, 1996.

- Carolina Maria de Jesus: emblema do silêncio. Biblioteca Virtual de

Direitos Humanos da USP. Disponível em: <http:/ / cefetsp.

br/edu/eso/cidadania/meihysp. html>. Acesso em: 24 jun. 2009.

RICHARD, N. Experiência e representação: o feminino, o latino-americano. In:_. Intervenções críticas: arte, cultura, gênero e política. Belo Horizonte: Editora UFMG, 2002. p. 142-155. 
PÊCHEUX, M. Semântica e discurso: uma crítica à afirmação do óbvio. Tradução de Eni Puccinelli Orlandi et al. Campinas, S.P: Editora da UNICAMP, 1997.

SANTOS, J.B.C. A instância enunciativa sujeitudinal. In: Sujeito e subjetividade. Uberlândia: EDUFU. Coleção Linguística in Focus. Vol. 6. 2009. p. 83-101.

SOARES, M. Letramento: um tema em três gêneros. 2. ed. Belo Horizonte, Autêntica, 1999.

SOUSA, G. H. P. de. Carolina Maria de Jesus - o estranho diário da escritora viralata. 2004. 262f. Tese (Doutorado em Teoria Literária) - Universidade de Brasília, Brasília (DF), 2004.

WOOLF, V. Um teto todo seu. Rio de Janeiro: Nova Fronteira, 1985.

Recebido em: 03/10/11. Aprovado em: 20/08/12.

Title: In the chinks of grimpy notebooks: Carolina Maria de Jesus' the testimonial embroidery Authors: Fabiana Rodrigues Carrijo; João Bôsco Cabral dos Santos

Abstract: This paper aims at approaching the writing by an author who reached farther than her social, economic and limited conditions would allow. It also proposes to examine the writings by Carolina Maria de Jesus as an indication of a conceptual re-meaning of a quotidian discourse, which is materialized by means of allegories of a difficult life. Such experiences will be demonstrated, considering the author's dislocation to the condition of subjective instance who reveals a discourse of social exclusion while bringing to literature such a kind of social portrait. It is registered in the theoretical contributions of AD (French), that this thesis project aims to look, closely, to the basic literary corpus, although incanonic, consisting in the work entitled "Quarto de Despejo - Diário de uma favelada", with a view to propose an interface that works together to sketch the processes of subjectivation; it also aims to outline what here is called the literary incanonic discursivity in Carolina Maria de Jesus.

Keywords: Literary discursivity. Writing. Carolina Maria de Jesus.

Titulo: En las grietas de los cuadernos mugrientos: el bordado testimonial de Carolina Maria de Jesus Autor: Fabiana Rodrigues Carrijo; João Bôsco Cabral dos Santos

Resumen: Este artículo objetiva refrendar la escritura de una autora que consiguió alzar vuelos más lejanos que las que sus limitadas condiciones socioeconómicas le impusieron. Propone, aun, develar que los escritos de Carolina Maria de Jesus indican una división conceptual del mundo a través de una resignificación del discurso del cotidiano y éste es materializado a través de alegorías severamente vividas. La instancia-sujeto autor coloca en la experiencia empirica de un discurso de la exclusión la real experiencia del hambre y hace de este experimento una forma de visión social. Está inscripto en los aportes teóricos de la $A D$ (francesa) que el presente articulo ambiciona ver para el corpus de base literaria, aun que incanónica, constituida por la obra intitulada Cuarto de Desalojo - Diario de una favelada, con vistas a proponer un trabajo en interface que, a la par de bosquejar los procesos de subjetivación, ambiciona, aun, delinear lo que estamos denominando discursividad literaria incanónica en Carolina Maria de Jesus.

Palabras-clave: Discursividad literaria. Escritura. Carolina Maria de Jesus.

Linguagem em (Dis)curso, Tubarão, SC, v. 12, n. 2, p. 415-438, maio/ago. 2012 